\title{
The impact of environmental factors on the occurrence of congenital heart disease in the form of hypoplastic left heart syndrome
}

\author{
Marcin Michał Gładki ${ }^{1}$, Tomasz Składzień ${ }^{2}$, Janusz Hieronim Skalski ${ }^{1}$ \\ 1Paediatric Cardiac Surgery Clinic, USD, Krakow, Poland \\ ${ }^{2}$ Anaesthesiology and Intensive Care Clinic, University Hospital, Krakow, Poland
}

Kardiochirurgia i Torakochirurgia Polska 2015; 12 (3): 204-207

\begin{abstract}
Introduction: Congenital heart defects are the most common abnormalities in neonatal age. Congenital heart defects occur with a frequency of 3-12/1000 births. A special group is constituted by children with hypoplastic left heart syndrome because their treatment is extremely complex, requiring threestage surgery and the involvement of various specialists.

Material and methods: We analysed 100 infants with congenital heart defects in the form of hypoplastic left heart syndrome (HLHS). They were compared with a control group of 100 newborns without structural heart defects. The children's parents were asked to fill out a questionnaire consisting of 10 simple questions. It had been constructed in consultation with a psychologist in order not to offend the feelings of the parents affected by the illness of their offspring.

Results: Congenital heart defects were present in the family medical histories of 16 HLHS children and 11 healthy children $(p=0.4)$. Genetic disorders were present in the family medical histories of 13 HLHS children and 15 healthy children $(p=0.73)$. In the HLHS group, the mothers smoked cigarettes or were exposed to tobacco smoke in $32 \%$ of cases; in the control group, this proportion amounted to $23 \%(p=0.76)$.

Conclusions: The study found no relationship between the occurrence of hypoplastic left heart syndrome in children and the parents' age, the presence of genetic disorders, or heart defects in the family medical histories.

Key words: congenital heart disease, HLHS, environmental factors.
\end{abstract}

\section{Introduction}

Heart defects are among the most common congenital defects in neonates. The incidence of congenital heart defects is estimated at 3-12 per 1000 births. This risk rises two-fold for premature infants. The congenital heart de-

\section{Streszczenie}

Wstęp: Wady serca to jedna z najczęstszych wrodzonych wad w wieku noworodkowym. Szacuje się, że wrodzone wady serca występują z częstością 3-12/1000 urodzeń. Szczególną grupę stanowią dzieci z niedorozwojem serca lewego (hypoplastic left heart syndrome - HLHS), gdyż ich leczenie jest niezwykle złożone - wymagają one trójetapowego leczenia chirurgicznego oraz zaangażowania lekarzy wielu specjalności.

Materiat i metody: W pracy przeanalizowano 100 przypadków żywo urodzonych noworodków z HLHS i porównano je z grupą kontrolną 100 noworodków bez strukturalnej wady serca poprzez przeprowadzenie anonimowej dobrowolnej ankiety wypełnionej przez rodziców. Ankieta składała się z 10 prosto sformułowanych pytań. Została ona skonstruowana po zasięgnięciu opinii psychologa, by nie urazić uczuć rodziców dziecka dotkniętego poważną strukturalną wadą serca.

Wyniki: W 16 rodzinach w grupie dzieci z HLHS występowały wrodzone wady serca, a w grupie dzieci zdrowych $w 11$ przypadkach $(p=0,4)$. W 13 rodzinach $w$ grupie dzieci z HLHS występowały wady genetyczne, a w grupie dzieci zdrowych w 15 przypadkach $(p=0,73)$. W grupie dzieci z HLHS podczas ciąży matka paliła papierosy lub była narażona na działanie dymu tytoniowego w 32\% przypadków, a w grupie zdrowych dzieci w 23\% przypadków $(p=0,76)$.

Wnioski: W obu grupach nie stwierdzono zależności pomiędzy wiekiem rodziców, wystąpieniem wad serca bądź wad genetycznych w rodzinie a wystąpieniem HLHS u dziecka.

Słowa kluczowe: wady wrodzone serca, HLHS, czynniki środowiskowe.

fects that are most frequently treated with surgery include ventricular septal defect, atrial septal defect, and patent ductus arteriosus [1].

The causes of heart defects remain unknown in $90 \%$ of cases. The factors that may influence their occurrence

Address for correspondence: Marcin Michał Gładki, MD, PhD, Pediatric Cardiac Surgery Clinic, USD, 265 Wielicka St., 30-663 Kraków, Poland, phone: +48 512167325, e-mail: marcingladki@gmail.com 
are widely considered to include genetic disorders, viral infections during pregnancy, the use of some types of medication and alcohol, and uncontrolled diabetes in the mother [2-5].

Epidemiological studies confirm the influence of the mother's exposure to polluted air on the occurrence of a congenital heart defect in the child [6-16].

Notwithstanding, the causes for the occurrence of many developmental defects, including hypoplastic left heart syndrome, remain unknown.

\section{Material and methods}

The study analysed 100 cases of live-born neonates with hypoplastic left heart syndrome and compared them with a control group of 100 neonates without structural heart defects by conducting an anonymous voluntary questionnaire among the children's parents. The questionnaire included 10 simple questions. A psychologist was consulted in order to avoid hurting the feelings of parents affected by the illness of their offspring. The questionnaire was conducted among the parents of the study group children undergoing surgery at the Clinic of Paediatric Cardiac Surgery (Collegium Medicum of the Jagiellonian University) between 2008 and 2014 and among the parents of randomly selected children free of heart defects born in obstetric wards in southern Poland.

Questionnaire:

1. Is this your first child? Yes/No

2. Please state the age of the mother.

3. Please state the age of the father.

4. Does your family's medical history include heart defects? Yes/No

5. Does your family's medical history include genetic disorders? Yes/No

6. Did the mother smoke cigarettes during the pregnancy/ was she exposed to tobacco smoke? Yes/No

7. Did the mother come in contact with other harmful substances (alcohol, chemicals, inebriants)? Yes/No

8. Did the mother take any medication during the pregnancy? Yes/No

9. Is it possible that the father was under the influence of any chemical substances (medication, tobacco smoke, alcohol, chemicals, inebriants) during the period around conception? Yes/No

10. What is your standard of living? Good/Moderate/Poor

The answers to these questions were not problematic to the respondents, and they participated in the questionnaire without reservations.

Statistical analysis of the results was conducted with the use of Student's $t$ test and the Mann-Whitney $U$ test (software used: Statistica 10.0). A value of $p<0.05$ was assumed to be statistically significant.

\section{Results}

First children of their parents constituted $44 \%$ of the HLHS group and $32 \%$ of the control group $(p=0.09)$.
The mean age of the mothers was $27.86 \pm 5.61$ years in the HLHS group and $26.43 \pm 5.85$ years in the control group $(p=0.08)$.

The mean age of the fathers was $30.74 \pm 5.39$ years in the HLHS group and $30.12 \pm 6.32$ years in the control group $(p=0.41)$.

Congenital heart defects were present in the family medical histories of 16 HLHS children and 11 healthy children $(p=0.4)$.

Genetic disorders were present in the family medical histories of 13 HLHS children and 15 healthy children ( $p=0.73$ ).

In the HLHS group, the mothers smoked cigarettes or were exposed to tobacco smoke in $32 \%$ of cases; in the control group, this proportion amounted to $23 \%(p=0.76)$.

In the HLHS group, the mothers had contact with other harmful substances in $25 \%$ of cases; in the control group, this proportion was $23 \%(p=0.25)$.

In the HLHS group, the mothers received medications for chronic illnesses in $25 \%$ of cases; in the control group, this proportion was $17 \%(p=0.42)$.

The fathers could have been under the influence of inebriant chemical substances in $28 \%$ of cases in the HLHS group and $34 \%$ of cases in the control group.

The parents of children with HLHS assessed their material status as good in 20 cases, moderate in 70 cases, and poor in 10 cases. The parents of healthy children assessed their material status as good in 26 cases, moderate in 54 cases, and poor in 20 cases $(p=0.64)$.

\section{Discussion}

Hypoplastic left heart syndrome is a common congenital heart anomaly in children, which continues to pose a therapeutic challenge. Despite numerous studies conducted in order to establish the causes of the occurrence of congenital heart defects in children, unambiguous determination of these causes remains elusive. Embryological studies point to the role of the period of cardiac development starting with cell migration from the primitive tubular heart and its differentiation into cardiac chambers and outflow tracts during the $7^{\text {th }} / 8^{\text {th }}$ week of development [17].

The factors that may potentially be responsible for the occurrence of heart defects in children include, among others, environmental pollution. Studies conducted by Stingone et al. have proven that women who gave birth to children with HLHS were twice as likely to live in neighbourhoods associated with higher exposure to pollutant particles $\leq 2.5 \mathrm{~m}$ than women who gave birth to children without this defect [18].

The significance of the age of the mother in the development of a congenital heart defect in the child is also underscored [19]; it is an independent risk factor for the development of congenital heart defects in neonates despite the lack of chromosomal anomalies. Among our respondents, no association was found between the age of the mothers of HLHS children and the age of the mothers of non-HLHS children, nor was there any association between the age of the fathers of HLHS and non-HLHS children. 
Another causative factor that may be responsible for the occurrence of a congenital heart defect in the child is the mother's obesity. Gilboa et al. and Mills et al. reported an association between HLHS occurrence and severe obesity in the mother: $\mathrm{BMI} 30.0-34.9 \mathrm{~kg} / \mathrm{m}^{2}$ and $\mathrm{BMI} 30.0-$ $39.9 \mathrm{~kg} / \mathrm{m}^{2}$, respectively [5, 20].

Genetic predisposition is an exceptionally important risk factor for the occurrence of congenital heart defects. Among our respondents, no statistical significance was associated with the presence of congenital heart defects in the family histories of HLHS and non-HLHS children. We also did not find any statistically significant difference between the groups regarding the presence of genetic disorders in the family. Notwithstanding, the progress made in the field of biotechnology is giving rise to an increasing number of publications investigating the genetic aspects of congenital heart defects. Menten et al. point to the relationship between the occurrence of congenital heart defects (including HLHS) and 22q11.2 microdeletion [21]. Grossfeld et al. reported that $56 \%$ of patients with Jacobsen syndrome have congenital heart defects, which very frequently includes HLHS [22].

A study conducted in Finland by Tikkanen et al. analysed 34 mothers of children with HLHS and compared them with a control group comprising mothers of randomly selected children born during the same period [23]. The study found a statistical relationship between the occurrence of upper respiratory tract infection in the mother during the first trimester of pregnancy and the development of HLHS in the child. However, it did not confirm the role of the mother's exposure to disinfectants, pesticides, dyes, hair sprays, paints, or inhalational anaesthetics in the development of HLHS in the child. The use of deodorants and hair sprays during the first trimester of pregnancy also had no bearing on the HLHS risk. The study found no influence of the use of alcohol, coffee, or tobacco by the mother on the risk of HLHS development in the child. In turn, Sullivan et al. reported that the mother's tobacco use is slightly or moderately associated with the development of pulmonary valve defects and atrial septal defects in the child [24]. The results of our questionnaire showed no association between HLHS development in the studied children and the use of tobacco or other harmful substances by their mothers.

The material status of parents of children with congenital heart defects was observed to directly influence survival [25]. The results of our questionnaire did not indicate any association between the family's material status and the occurrence of HLHS.

\section{Conclusions}

In the studied material, no association was found between the occurrence of hypoplastic left heart syndrome in children and the parents' age, material status, and use of medications, tobacco, and inebriants, or the presence of genetic disorders in the family medical histories.

\section{Disclosure}

Authors report no conflict of interest.

\section{References}

1. Hoffman J, Kaplan S. The incidence of congenital heart disease. J Am Coll Cardiol 2002; 39: 1890-1900.

2. Sun R, Liu M, Lu L, Zheng Y, Zhang P. Congenital heart disease: causes, diagnosis, symptoms, and treatments. Cell Biochem Biophys 2015 [Epub ahead of print].

3. Aberg A, Westbom L. Association between maternal pre-existing or gestational diabetes and health problems in children. Acta Paediatrica 2001; 90: 746-750.

4. Aberg A, Westbom L, Kallen B. Congenital malformations among infants whose mothers had gestational diabetes or preexisting diabetes. Early Human Development 2001; 61: 85-95.

5. Gilboa SM, Correa A, Botto LD, Rasmussen SA, Waller DK, Hobbs CA, Cleves MA, Riehle-Colarusso TJ. Association between prepregnancy bodymass index and congenital heart defects. Am J Obstet Gynecol 2010; 202: 51.e1-51. e10.

6. Agay-Shay K, Friger M, Linn S, Peled A, Amitai Y, Peretz C. Air pollution and congenital heart defects. Environ Res 2013; 124: 28-34.

7. Dadvand P, Rankin J, Rushton S, Pless-Mulloli T. Ambient air pollution and congenital heart disease: aregister-based study. Environ Res 2011; 111: 435441.

8. Dadvand P, Rankin J, Rushton S, Pless-Mulloli T. Association between maternal exposure to ambient air pollution and congenital heart disease: a register-basedspatiotemporal analysis. Am J Epidemiol 2011; 173: 171-182.

9. Dolk H, Armstrong B, Lachowycz K, Vrijheid M, Rankin J, Abramsky L, Boyd PA, Wellesley D. Ambient air pollution and risk of congenital anomalies in England, 1991-1999. Occup Environ Med 2010; 67: 223-227.

10. Gilboa SM, Mendola P, Olshan AF, Langlois PH, Savitz DA, Loomis D, Herring $\mathrm{AH}$, Fixler DE. Relation between ambient air quality and selected birth defects, seven county study, Texas,1997-2000. Am J Epidemiol 2005; 162: 238-252.

11. Hansen CA, Barnett AG, Jalaludin BB, Morgan GG. Ambient air pollution and birth defects in Brisbane, Australia. PLoS One 2009; 4: e5408.

12. Padula AM, Tager IB, Carmichael SL, Hammond SK, Yang W, Lurmann F, Shaw GM. Ambient air pollution and traffic exposures and congenital heart defects in the San Joaquin Valley of California. Paediatr Perinat Epidemiol 2013; 27: 329-339.

13. Rankin J, Chadwick T, Natarajan M, Howel D, Pearce MS, Pless-Mulloli T. Maternal exposure to ambient air pollutants and risk of congenital anomalies. Environ Res 2009; 109: 181-187.

14. Ritz B, Yu F, Fruin S, Chapa G, Shaw GM, Harris JA. Ambient air pollution and risk of birth defects in Southern California. Am J Epidemiol 2002; 155: 17-25.

15. Strickland MJ, Klein M, Correa A, Reller MD, Mahle WT, Riehle-Colarusso TJ, Botto LD, Flanders WD, Mulholland JA, Siffel C, Marcus M, Tolbert PE. Ambient air pollution and cardiovascular malformations in Atlanta, Georgia, 1986-2003. Am J Epidemiol 2009; 169: 1004-1014.

16. Vrijheid M, Martinez D, Manzanares S, Dadvand P, Schembari A, Rankin J, Nieuwenhuijsen M. Ambient air pollution and risk of congenital anomalies: a systematic review and meta-analysis. Environ Health Perspect 2011; 119: 598-606.

17. Gittenberger-de Groot AC, Bartelings MM, Deruiter MC, Poelmann RE. Basics of cardiac development for the understanding of congenital heart malformations. Pediatr Res 2005; 57: 169-176.

18. Stingone JA, Luben TJ, Daniels JL, Fuentes M, Richardson DB, Aylsworth AS, Herring AH, Anderka M, Botto L, Correa A, Gilboa SM, Langlois PH, Mosley B, Shaw GM, Siffel C, Olshan AF. Maternal exposure to criteria air pollutants and congenital heart defects in offspring: results from the national birth defects pevention study. Environ Health Perspect 2014; 122: 863-872.

19. Schulkey CE, Regmi SD, Magnan RA, Danzo MT, Luther H, Hutchinson AK, Panzer AA, Grady MM, Wilson DB, Jay PY. The maternal-age-associated risk of congenital heart disease is modifiable. Nature 2015; 520: 230-233.

20. Mills JL, Troendle J, Conley MR, Carter T, Druschel CM. Maternal obesity and congenital heart defects: a population-based study. Am J Clin Nutr 2010; 91: 1543-1549.

21. Menten B, Maas N, Thienpont B. Emerging patterns of cryptic chromosomal imbalance in patients with idiopathic mental retardation and multiple con- 
genital anomalies: a new series of 140 patients and review of published reports. J Med Genet 2006; 43: 625-633.

22. Grossfeld PD, Mattina T, Lai Z, Favier R, Jones KL, Cotter F, Jones C. The 11q terminal deletion disorder: a prospective study of 110 cases. Am J Med Genet A 2004; 129A: 51-61.

23. Tikkanen J, Heinonen OP. Risk factors for hypoplastic left heart syndrome. Teratology 1994; 50: 112-117.
24. Sullivan PM, Dervan LA, Reiger S. Risk of congenital heart defects in the offspring of smoking mothers: a population-based study. J Pediatr 2015; 166: 978-984.e2.

25. Kucik JE, Nembhard WN, Donohue P. Community socioeconomic disadvantage and the survival of infants with congenital heart defects. Am J Public Health 2014; 104: e150-157. 